\title{
Design and Validation of an Assessment Tool for Educational Mobile Applications Used with Autistic Learners
}

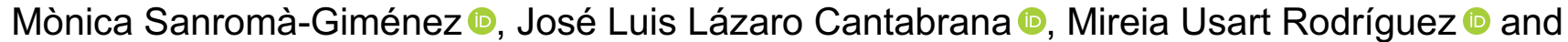 \\ Mercè Gisbert-Cervera (1)
}

Department of Pedagogy, Universitat Rovira i Virgili, Spain

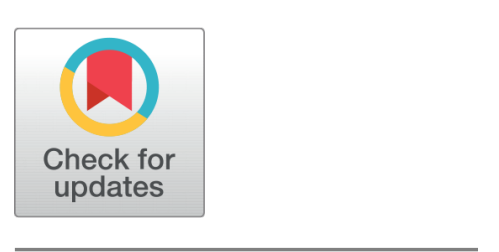

Received 2020-03-31
Revised 2020-04-03
Accepted 2020-09-08
Published 2021-01-15

Corresponding Author Mònica Sanromà-Giménez, monica.sanroma@urv.cat

Universitat Rovira i Virgili, Facultat de Ciències de l'Educació i Psicologia, Campus Sescelades, Carretera de Valls, s/n, 43007, Tarragona (Spain)

DOI https://doi.org/10.7821/

naer.2021.1.574

Pages: 101-121

Funding: Secretaría de Universidades de la Generalitat de Catalunya \& European Social Found, Spain (Award: 2017FI_B 00489); Ministry of Science, Innovation and Universities, Spain (Award:

RTI2018-096815-B-I00)

Distributed under

Creative Commons CC BY 4.0

Copyright: (C) The Author(s)

\section{OPEN ACCESS}

\section{ABSTRACT}

This work presents the design and validation process for a tool to evaluate educational mobile applications for autistic learners. The project was developed in several stages. First, we reviewed and analysed the literature. Second, we conducted a Delphi study with experts $(\mathrm{n}=12)$ from different backgrounds (educational technology, accessibility, app developers and autism specialist teachers) selected using the calculated expert competence coefficient. And finally, we conducted a pilot test with trainee $(n=51)$ and in-service $(n=9)$ teachers who evaluated a selection of 11 apps. The data collected was used to study the factor structure of the tool, its reliability and usability. In this paper we present the resulting questionnaire consisting of 36 items grouped into six sections: "Information about the evaluator", "Technical and descriptive characteristics", "Pedagogical characteristics in relation to autism", "General pedagogical characteristics", "Characteristics for educational inclusion and accessibility", and "Professional satisfaction". The results condense the questionnaire to two factors and indicate that the tool is valid, reliable and useful for assessing the properties of apps and for facilitating the learning process of people with autism.

\section{Keywords AUTISM, EDUCATIONAL TECHNOLOGY, EVALUATION, INCLUSIVE EDUCATION, MOBILE LEARNING}

\section{INTRODUCTION}

The Salamanca Declaration (UNESCO, 1995) called upon education systems to guarantee the same educational opportunities to all learners, and in particular, to those with special educational needs. To this end, lines of actions were developed to offer equitable, highquality education under the principle of 'education for all' and 'inclusive education' (Booth \& Ainscow, 2002; Echeita \& Ainscow, 2011). This goal was manifested in global initiatives like the 2030 Agenda for Sustainable Development and its educational objectives (ODS4) (UNESCO, 2016). In this context, the digitalisation of our society, and ultimately of education, has made digital technologies (DT) an essential resource for maximising opportunities 
for learning and participation, especially among more vulnerable groups (Eynon, 2009; Selwyn, 2004). It is based on this view that we have approached the use of DT as an assistive technology (Lancioni, Sigafoos, O’Reilly, \& Singh, 2012). UNESCO (2019, p. 13) makes special mention of this in its assertation that 'assistive technologies when harnessed effectively provide an opportunity for people with disabilities in educational settings to access information and participate fully'. The universalisation of mobile devices or technologies (mainly tablets and smartphones) for pedagogical and educational purposes has given rise to what is known as "mobile learning" (UNESCO, 2013; Wu et al., 2012). When used effectively by teachers and learners, these 'can advance equity of education, improve efficiency and productivity in the classroom, and facilitate personalised learning' (UNESCO, 2019, p. 14). Therefore, mobile learning plays an extraordinary role in the education of people with disabilities, especially when the properties of these devices facilitate their use: 'affordability, a mainstream device, built-in accessibility features and easy to use and effective design' (McQuiggan, Kosturko, McQuiggan \& Sabourin, 2015, p. 283).

The definition of the condition of autism, from the perspective of abilities, is associated with meticulosity, curiosity, specialised knowledge in topics of interest, honesty, logic, the ability to listen, as well as many other traits (Autismo España, 2020). Elsewhere, and taking as a reference the latest version of the Diagnostic and Statistical Manual of Mental Disorders (DSM-5) (APA, 2013), autism spectrum disorder (ASD) is defined as a set of neurodevelopmental disorders characterised by deficits in social communication and interaction in various contexts, as well as by the presence of restrictive and repetitive patterns of behaviour, interests or activities. Attending to people on the autism spectrum through educational intervention is fundamental to promoting their quality of life (Barthélémy, Fuentes, Howlin, \& Gaag, 2019; Vidriales, Hernández, Plaza, Gutiérrez, \& Cuesta, 2017). In this context, mobile devices and mobile applications (apps) are resources that make the teachinglearning process (T-L) more flexible and personalised, providing the learner with different ways of perceiving, understanding, committing to, participating and interacting with his or her own educational process in accordance with his or her needs and potential (Boser, Goodwin, \& Wayland, 2014; Hitchcock \& Stahl, 2003; Roldán-Álvarez, Gomez, MárquezFernández, Martín, \& Montoro, 2016). Apps undeniably add educational value to mobile devices that, without them, would lose much of their potential for learning (Allen, Hartley, \& Cain, 2016). According to Cabielles-Hernández et al. (2016, p. 184) apps offer 'a controllable situation and environment; present a multisensorial (mainly visual) stimulation; engagement ability; develop self-control skills and an active learning element with versatility, flexibility and adaptation.' For all these reasons, a great number of educational intervention apps have been developed for people with autism, and are available both in educational and general digital shops and catalogues: App Store (Apple, 2020), Play Store (Google, 2020), Toolbox (mSchools, 2020), Appy Autism (Fundación Orange \& iAutism, 2014), Autism Apps (Autism Association of Western Australia., 2020), etc. Faced with an endless list of possibilities, it cannot be assumed that all of the apps available on the internet are effective or appropriate for use by autistic learners in an educational intervention context (Sanromà-Giménez, Lázaro-Cantabrana, \& Gisbert-Cervera, 2017). In this regard, the 
symbiosis between educators and app developers is worth mentioning, as they must collaborate with one another to improve the quality of these types of digital resources (FletcherWatson, 2015).

The correct use of both mobile devices and apps for meeting the educational needs of autistic learners depends to a great extent on the ability of educators to evaluate and choose them, in addition to consistently including them in the T-L process (Navarro, Zervas, Gesa, \& Sampson, 2016). It is for this reason that all teachers, and especially special education teachers (Schaaf, 2018), must be digitally competent and undergo continuous professional development. Teacher digital competence (TDC) is an essential tool for effective teaching in the context of a digital, global, changing society (European Commission, 2021), as its development fosters the digital literacy of learners and the use of DT for educational inclusion and accessibility (Lázaro, Estebanell, \& Tedesco, 2015). Hence, the international and national standards of reference that define TDC (Cantabrana \& Cervera, 2015; Generalitat de Catalunya, 2018; INTF, 2017; Redecker \& Punie, 2017) contain a series of teacher training goals that include:

- The assessment and creation of digital educational resources.

- The use of DT for the universalisation of learning and the participation of all learners.

\section{PROBLEM AND RESEARCH OBJECTIVE}

Given the extensive range of educational apps available for use with autistic learners, it is essential that teachers establish clear and objective evaluation criteria which will allow them to identify the educational-pedagogical and technological characteristics that these resources should meet in order to facilitate learning. At the same time, these criteria must form the basis for the design of assessment tools that guide educators in this complex task: choosing the most suitable app for every learner and every educational context that most closely matches both learner characteristics and meets learner needs.

The aim of this work is to study the validity, reliability and usability of an assessment tool for educational intervention apps used with autistic learners: Educational Mobile Application Assessment Tool for Autism Spectrum Disorder (EMAAT for ASD).

\section{METHOD}

The tool was developed as part of a study based on educational design research (EDR) (Akker, Gravemeijer, Mckenney, \& Nieveen, 2006; Plomp \& Nieveen, 2013), an approach widely used in the field of educational technology (Benito \& Salinas, 2016). Several successive cycles of design, development and evaluation were applied to the instrument (prototypes) as iterations that have made it possible to address the specificity of the research problem from a theoretical and practical perspective. Professionals from a wide variety of backgrounds participated in the study and different data collection and analysis collection and analysis methods were used over the course of the various research cycles (Figure 1). We first reviewed and analysed the relevant literature, then we consulted 
a panel of experts using a Delphi study, and lastly, we piloted the test.
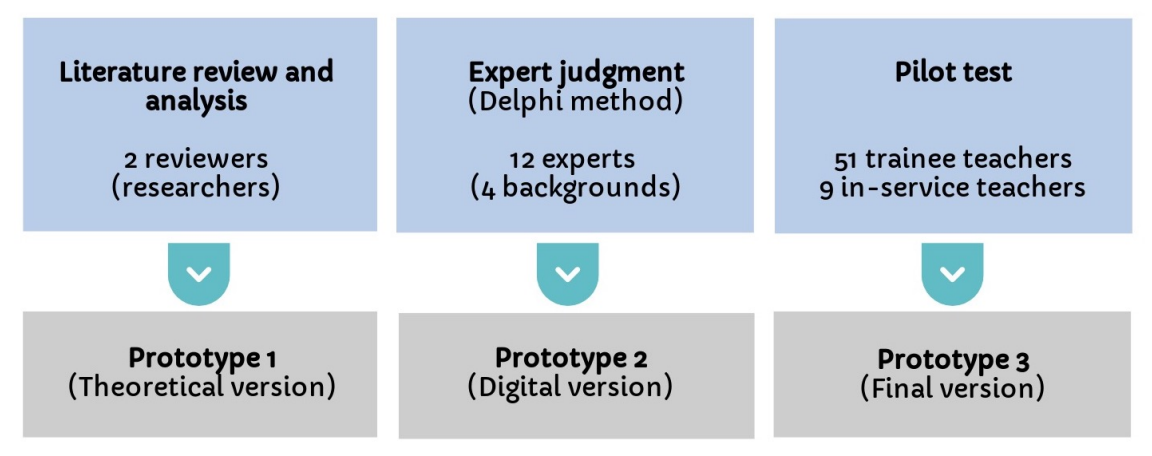

Figure 1 Summary of the EMAAT for ASD design and validation process.

\subsection{Literature Review and Analysis}

Using the PRISMA model (Moher, Liberati, \& Tetzlaff, 2009), we conducted a systematic qualitative and collaborative review of the scientific literature (Ferreira-González, Urrútia, \& Alonso-Coello, 2011; Petticrew \& Roberts, 2006) published between 2014 and 2018 related to the use of DTs in educational interventions with autistic learners (SanromàGiménez, Molero-Aranda, Lázaro-Cantabrana, \& Gisbert-Cervera, 2018). The content analysis of the works selected allowed us to identify three major categories of study: those centred on experimental and practical aspects, those concerning primarily theoretical aspects, and those addressing learning technology design. For the design of the EMAAT for ASD, our focus was on this last category of studies $(n=34)$, which consisted of works on principles of inclusive design for the creation of digital educational resources suitable for educational interventions with people with autism, that is to say, resources which meet the educational needs of this population. The analysis of these works served to identify the educational-pedagogical and technological characteristics to be considered in the evaluation of this type of resource. Other complementarily types of work not identified in the systematic review but considered to be of great importance for the design and rationale of the EMAAT for ASD were also analysed. Firstly, we looked at three international frameworks of reference and standards addressing the universalisation of access to and use of technologies for learning and participation within the context of a digital social and educational environment:

- Universal design for learning (UDL) (CAST, 2018)

- Web Content Accessibility Guidelines (W3C, 2015; 2018).

- Cognitive Accessibility User Research (W3C, 2015)

Secondly, we examined other proposals for evaluation criteria and general and specific educational app evaluation tools or questionnaires for students with special educational needs:

- Mobile App Rating Scale (Stoyanov et al., 2015). 
- Evaluation manual from the Toolbox website (mSchools, 2020).

- Validation of a Tool Evaluating Educational Apps for Smart Education (Lee \& Kim, 2015).

- Rubric for the Evaluation of Educational Apps for Preschool Children (REVEAC) (Papadakis, Kalogiannakis, \& Zaranis, 2017).

- Evaluation Rubric for Instructional Apps for Teaching Students with Learning Disabilities (Ok, Kim, Kang, \& Bryant, 2016).

- App Evaluation Rubric for Practitioners in Special Education (Weng, 2015).

- The Great App Checklist (Mcquiggan et al., 2015).

- A Proposal for a Unified Framework for the Design of Technologies for People with Learning Difficulties (Seale, Garcia-Carrisoza, Rix, Sheehy, \& Hayhoe, 2018).

In summary, the review and in-depth analysis of all these documents made it possible to design the first prototype of the EMAAT for ASD, as these works provided a theoretical basis for its structure and content and highlighted the relevance of key aspects related to educational-pedagogical characteristics and the digital accessibility of the apps.

\subsection{Panel of Experts}

We used the Delphi method (Álvarez \& Fonseca, 2016; López-Gómez, 2018) as an expert panel technique (Escobar-Pérez \& Cuervo-Martínez, 2008) to analyse the validity of the content and the relevance of the EMAAT for ASD.

\subsubsection{Selection and Composition of the Panel of Experts}

Because the configuration of the panel of experts is a central concern in this type of study, we adhered to the most relevant consensus criteria for forming these types of panels (Cabero, 2014; Escobar-Pérez \& Cuervo-Martínez, 2008; López-Gómez, 2018): recognition and relevance in the research topic (knowledge and know-how) and willingness and availability to participate in the study. In addition, we identified four professional profiles capable of contributing multiple levels of insight to our research:

- Educational technology

- Accessibility

- App development

- In-service educators specialising in autism

The number of experts was determined based on the work of López-Gómez (2018), who report that in Delphi studies with multidisciplinary groups, such as in this case, the panel is usually made up of no fewer than 12 experts. These authors also indicate that this figure represents a compromise between the reliability of the results and the time dedication of the experts. Therefore, we decided on a panel size of 10 to 15 experts.

To ensure the quality of the panel, the experts were selected using the expert competence coefficient, or K coefficient (Almenara \& Osuna, 2013; Mengual-Andrés, 2011). In 
this procedure, it is the experts themselves who evaluate their depth of knowledge about the subject matter addressed in the research (knowledge coefficient, $\mathrm{Kc}$ ), as well as their familiarity with sources that would allow them to defend their opinions (argumentation coefficient, Ka). The index is calculated using the formula $\mathrm{K}=1 / 2(\mathrm{Kc}+\mathrm{Ka})$. Finally, the result of the expert competence index is a score between 0 and 1 in which a score of 0.8 or higher corresponds to high degree of expert competence (Osuna, Gutiérrez-Castillo, del Carmen Llorente-Cejudo, \& Ortiz, 2019).Table 1 shows the results obtained by the 33 potential experts we surveyed, of which 12 were chosen, distributed equally among the expertise groups.

Table 1 Knowledge coefficient $(\mathrm{Kc})$, argumentation coefficient (Ka) and expert competence coefficient (K) for each expert.

\begin{tabular}{|c|c|c|c|c|}
\hline & Expert & Kc & Ka & $\mathbf{K}$ \\
\hline \multirow[t]{9}{*}{ Educational technology } & 1 & 0,8 & 0,95 & 0,875 \\
\hline & 2 & 0,8 & 1 & 0,9 \\
\hline & 3 & 0,9 & 1 & 0,95 \\
\hline & 4 & 0,7 & 0,6 & 0,65 \\
\hline & 5 & 0,9 & 0,95 & 0,925 \\
\hline & 6 & 0,7 & 0,85 & 0,775 \\
\hline & 7 & 0,6 & 0,95 & 0,775 \\
\hline & 8 & 0,2 & 0,5 & 0,35 \\
\hline & 9 & 0,8 & 0,85 & 0,825 \\
\hline \multirow[t]{6}{*}{ Accessibility } & 10 & 0,8 & 0,9 & 0,85 \\
\hline & 11 & 0,7 & 1 & 0,85 \\
\hline & 12 & 1 & 1 & 1 \\
\hline & 13 & 0,8 & 1 & 0,9 \\
\hline & 14 & 0,7 & 0,85 & 0,775 \\
\hline & 15 & 0,9 & 0,95 & 0,925 \\
\hline \multirow[t]{6}{*}{ App development } & 16 & 0,9 & 0,95 & 0,925 \\
\hline & 17 & 0,7 & 0,75 & 0,725 \\
\hline & 18 & 1 & 0,95 & 0,975 \\
\hline & 19 & 0,9 & 1 & 0,95 \\
\hline & 20 & 0,7 & 0,7 & 0,7 \\
\hline & 21 & 0,9 & 1 & 0,95 \\
\hline \multirow[t]{12}{*}{ Autism specialist educators } & 22 & 0,8 & 0,7 & 0,75 \\
\hline & 23 & 0,9 & 0,95 & 0,925 \\
\hline & 24 & 0,6 & 0,7 & 0,65 \\
\hline & 25 & 0,8 & 0,85 & 0,825 \\
\hline & 26 & 0,7 & 0,8 & 0,75 \\
\hline & 27 & 0,6 & 0,8 & 0,7 \\
\hline & 28 & 0,4 & 0,7 & 0,55 \\
\hline & 29 & 0,4 & 0,6 & 0,5 \\
\hline & 30 & 0,7 & 0,85 & 0,775 \\
\hline & 31 & 0,8 & 0,8 & 0,8 \\
\hline & 32 & 0,8 & 1 & 0,9 \\
\hline & 33 & 0,5 & 0,8 & 0,65 \\
\hline
\end{tabular}

The profiles of the experts that participated in the study are described below: 
- Sex: eight women and four men.

- Institutions: Spanish universities $(n=6)$, foreign universities $(n=3)$, public administration $(\mathrm{n}=2)$, private institutions $(\mathrm{n}=2)$.

- Areas of professional experience: compulsory education, psychology, web accessibility and educational inclusion.

\subsubsection{Implementation of Assessment Rounds}

Two predetermined assessment rounds were held. This was the model established for the completion of the review process. We excluded the consensus and stability study between rounds for this project. This variation in the method was adopted due to our concern with maintaining the interest and involvement of the panel of experts towards the task at hand (Cabero, 2014).

In the first round, the experts applied a validation instrument to evaluate the clarity (yes/no), and the relevance or importance of every item, both on a scale of 1 (not very relevant/important) to 4 (very relevant/important). They also provided qualitative assessments (observations). In the second round, the experts evaluated a new version of the tool, which included indications and recommendations they had given in the previous round. The tool was evaluated by means of an online questionnaire in which all the experts where asked to rate their degree of satisfaction with the new version on a scale of 1 (not very satisfied) to 4 (very satisfied) based on the changes made in each of the sections of the tool. On this occasion, the experts were also provided a space in which to add their observations. The Delphi study concluded by sending a letter to the experts notifying them of the completion of the review process and thanking them for their participation in this research project. A report was attached containing the updated version of the instrument (prototype 2).

In summary, the panel of experts phase of the study resulted in the second EMAAT for ASD prototype, which was also created digitally (online questionnaire) with the opensource software LimeSurvey.

\subsection{Pilot Test}

In order to study the factor structure, reliability, criteria validity and usability of the EMAAT for ASD, the instrument was pilot tested with a sample of 51 trainee teachers ( 40 women and 11 men) and 9 in-service teachers ( 1 man and 8 women). The pilot test was conducted in accordance with the sequence of activities shown in Figure 2. The procedure used for the selection of the sample was non-probabilistic, causal and intentional, as the sample is made up of people who are easily accessible but who are also considered relevant as sources of information (Sabariego, 2009). For the trainee teachers, the pilot was presented as a formative activity in the framework of two subjects included in the degree coursework for the Primary Education and Pedagogy programme at Universitat Rovira i Virgili (ICT Resources and Inclusive Education, Resources for Attending to Diversity in Young Learners), which specifically address inclusive technology and digital technologies. The in-service teachers are employed at different schools in the region and make use of mobile devices and apps in 
their work with autistic learners.

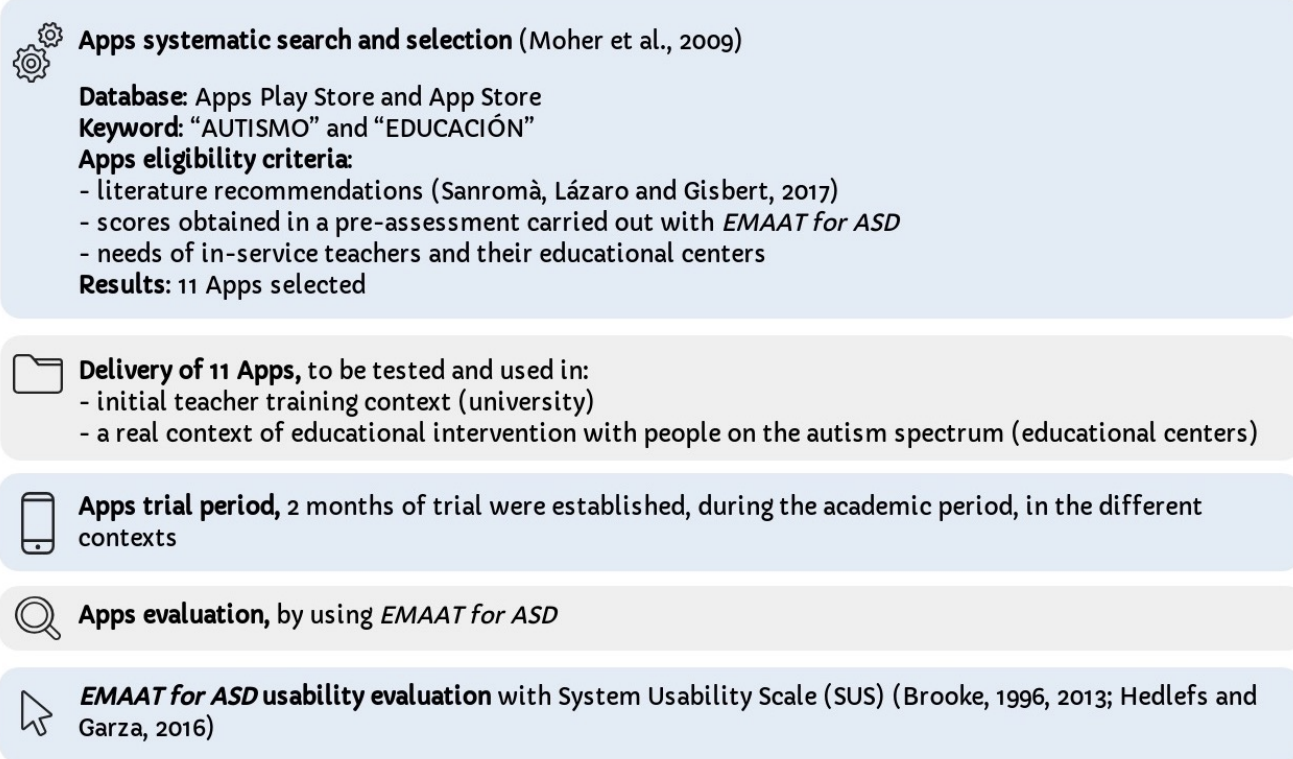

Figure 2 Pilot test sequence

In short, the conclusion and the analysis of the data collected during the pilot test allowed us to develop the final version (prototype 3 ) of the EMAAT for ASD.

\section{RESULTS}

A descriptive quantitative analysis was performed using the results obtained in the content validation phase with the panel of experts (Delphi method). Next, using the data collected through the pilot test, the factor structure of the semi-quantitative part of the tool was analysed. First the factor structure was studied using a principal component analysis (PCA), then the reliability of the scales was measured with Cronbach's Alpha (Dunn, Baguley, \& Brunsden, 2014), and finally the criteria validity was calculated (Landis \& Koch, 1977), which is key in this type of evaluation instrument provided that a "standard" or expert assessment is available. To do this, the evaluations using the EMAAT for ASD for the same three apps from one in-service teacher (considered an expert) and three trainee teachers (considered non-experts) were chosen and Spearman's correlation coefficient was calculated using the scores obtained from the two groups of teachers. Lastly, teachers' perceptions of the usability of the EMAAT for ASD were measured using the all-positive version of the system usability scale (SUS) (Brooke, 1996, 2013) translated to Spanish (Aguilar \& Villegas, 2016). The data was analysed using quantitative data analysis software (JASP V.0.1.11). 


\subsection{Panel of Experts}

\subsubsection{First Round}

Overall, the experts rated many of the items included on the EMAAT for ASD as highly clear, relevant and important (Table 2). This assessment also extended to the results of the five sections grouped together in reference to clarity criteria (Table 3). A detailed analysis of all this information allowed us to recreate the instrument and justify our modifications, resulting in an improved version of the tool. The modifications made were essentially the following:

- Section 1. Although the experts' assessment of the clarity of this section was positive, several modifications were made to improve it: clarifying information was added, the names of several items were modified or replaced, and the presentation and order of the items were reorganised based on whether they addressed the technical or descriptive characteristics of the apps. There was no clear consensus in the relevance and importance criteria for any of the items, although our attention was drawn to several of them (1.2, 1.3, 1.4, 1.5, 1.7 and 1.10). Item 1.4 was eliminated ("última actualización") and merged with item 1.3 ("versión").

- Section 2. The overall results for the clarity of this section were unfavourable and were lower than those received for any other section. However, the assessments for each item were positive. Positive relevance and importance ratings were given for the items proposed in this section. Item 2.1 ("descripción adecuada") was eliminated and a new item was added to assess the app's capacity to facilitate tracking and evaluation of the learning process.

- Section 3. In general, this section was rated as the second clearest, although it was mentioned that the language used was technical. With regard to relevance and importance, item 3.1 ("funciones cognitivas") was unanimously assessed as very relevant and important. The modifications focused on clarifying the formulation of the aspects to be evaluated, with minimal alterations to content or language, which is closely linked to solid theoretical references (APA, 2013; W3C, 2015). A new item was also added concerning ASD severity levels.

- Section 4. 75\% of the experts assessed this section as clear. However, its clarity was improved by reviewing the content of all the items, seeking to simplify them as much as possible, while respecting their theoretical basis (CAST, 2018; W3C, 2018). The relevance and importance results showed a certain tendency to rate items $4.1,4.2$ and 4.3 more positively. These items correspond to one of the UDL principle (CAST, 2018), and focus on assessing the capacity to present information in multiple ways. No items were eliminated or added.

- Section 5. This section was generally rated as the clearest. The experts rated all of the items as relevant and important, although item 5.4 ("valoración global") was particularly positive. An additional item was included to briefly qualitatively assess the apps in terms of their educational value and suitability for the proposed audience. 
Table 2 Results of the clarity, relevance and importance criteria by item (panel of experts)

Item

Clarity

Relevance

Importance

\begin{tabular}{|c|c|c|c|c|c|c|c|c|c|c|c|c|c|c|c|c|c|c|c|}
\hline & $\mathrm{Dk} / \mathrm{Di}$ & Yes & No & M & SD & $\mathrm{Dk} / \mathrm{D}$ & None & Few & Quite & Very & M & SD & $\mathrm{Dk} / \mathrm{D}$ & None & Few & Quite & Very & M & SD \\
\hline 1.1 Nombre & & 100 & & 1 & 0 & & & & & 100 & 4 & 0 & & & & 8,3 & 91,7 & 3,9 & ,2 \\
\hline 1.2 Desarrollador & & 100 & & 1 & 0 & & & & 33,3 & 66,7 & 3,6 & 4 & & 8,3 & & 41,7 & 50 & 3,3 & 8 \\
\hline 1.3 Versión & & 91,7 & 8,3 & 1,0 & ,2 & & & & 8,3 & 91,7 & 3,9 & ,2 & & & 25 & 8,3 & 66,7 & 3,4 & ,9 \\
\hline 1.4 Última actualización & & 100 & & 1 & 0 & & 8,3 & & 25 & 66,7 & 3,5 & ,9 & & 16,7 & 8,3 & 25 & 50 & 3,0 & 1,1 \\
\hline 1.5 Precio & & 91,7 & 8,3 & 1,0 & ,2 & & & & 16,7 & 83,3 & 3,8 & ,3 & & 8,3 & & 25 & 66,7 & 3,5 & ,9 \\
\hline 1.6 Sistema operativo & & 100 & & 1 & 0 & & & & 8,3 & 91,7 & 3,9 & ,2 & & & & 8,3 & 91,7 & 3,9 & ,2 \\
\hline 1.7 Catálogo & & 58,3 & 41,7 & 1,4 &, 5 & 8,3 & & 8,3 & 33,3 & 50 & 3,1 & 1,1 & 8,3 & 8,3 & 16,7 & 25 & 41 & 2,8 & 1,3 \\
\hline 1.8 Idioma & & 100 & & 1 & 0 & & & 8,3 & 8,3 & 83,3 & 3,7 & 6 & & & 16,7 & 8,3 & 75 & 3,5 &, 7 \\
\hline 1.9 Grupo de edad & & 100 & & 1 & 0 & & & & & 100 & 4 & 0 & & 8,3 & & & 91,7 & 3,7 & ,8 \\
\hline 1.10 Tipología & 8,3 & 75 & 16,7 & 1,0 &, 5 & 16 & & & 16,7 & 66,7 & 3,1 & 1,5 & 16,7 & 8,3 & & 16,7 & 58,3 & 2,9 & 1,6 \\
\hline 1.11 Breve descripción & 8,3 & 75 & 16,7 & 1,0 &, 5 & 8,3 & & 8,3 & 8,3 & 75 & 3,4 & 1,2 & 8,3 & & 8,3 & & 83,3 & 3,5 & 1,2 \\
\hline 2.1 Descripción adecuada & 8,3 & 91,7 & & 0,9 & ,2 & & 8,3 & & 8,3 & 83,3 & 3,6 & ,8 & & & & 16,7 & 83,3 & 3,8 & ,3 \\
\hline 2.2 Objetivos educativos & & 75 & 25 & 1,2 &, 4 & & 8,3 & & 8,3 & 83,3 & 3,6 & ,8 & & & 8,3 & & 91,7 & 3,8 &, 5 \\
\hline 2.3 Calidad de los contenidos & & 75 & 25 & 1,2 & ,4 & & & 8,3 & & 91,7 & 3,8 &, 5 & & & 8,3 & & 91,7 & 3,8 &, 5 \\
\hline 2.4 Evidencias científicas & & 83,3 & 16,7 & 1,1 &, 3 & & 8,3 & 16,7 & & 75 & 3,4 & 1,0 & & 16,7 & 8,3 & & 75 & 3,3 & 1,2 \\
\hline 3.1 Funciones cognitivas & & 100 & & 1 & 0 & & & & & 100 & 4 & 0 & & & & & 100 & 4 & 0 \\
\hline 3.2 Áreas afectación & & 100 & & 1 & 0 & 16,7 & & 8,3 & 8,3 & 66,7 & 3,0 & 1,5 & 16,7 & & 8,3 & 8,3 & 66,7 & 3,0 & 1,5 \\
\hline 4.1 Percepción & & 91,7 & 8,3 & 1,0 & ,2 & & & & 8,3 & 91,7 & 3,9 & , 2 & & & & 8,3 & 91,7 & 3,9 & ,2 \\
\hline 4.2 Lenguaje & & 91,7 & 8,3 & 1,0 & ,2 & & & & & 100 & 4 & 0 & & & & & 100 & 4 & 0 \\
\hline 4.3 Comprensión & & 83,3 & 16,7 & 1,1 &, 3 & & & & & 100 & 4 & 0 & & & 8,3 & & 91,7 & 3,8 &, 5 \\
\hline 4.4 Interacción & & 75 & 25 & 1,2 & ,4 & & & & 16,7 & 83,3 & 3,8 & ,3 & & & 8,3 & 8,3 & 83,3 & 3,7 & 6 \\
\hline $\begin{array}{l}4.5 \text { Expresión y comuni- } \\
\text { cación }\end{array}$ & & 91,7 & 8,3 & 1,0 & ,2 & & & & 41,7 & 58,3 & 3,5 &, 5 & & & & 33,3 & 66,7 & 3,6 & ,4 \\
\hline 4.6 Funciones ejecutivas & & 91,7 & 8,3 & 1,0 & ,2 & & & & 25 & 75 & 3,7 & ,4 & & & 8,3 & 16,7 & 75 & 3,6 & 6 \\
\hline 4.7 Interés & & 100 & & 1 & 0 & & & 8,3 & 8,3 & 83,3 & 3,7 & 6 & & & & 16,7 & 83,3 & 3,8 & 3 \\
\hline 4.8 Esfuerzo y persistencia & & 91,7 & 8,3 & 1,0 & ,2 & 16 & & & 25 & 58,3 & 3,0 & 1,5 & 16,7 & & 8,3 & 16,7 & 58,3 & 3 & 1,5 \\
\hline 4.9 Autorregulación & & 83,3 & 16,7 & 1,1 &, 3 & 16 & & & 8,3 & 75 & 3,2 & 1,5 & 16,7 & & & 25 & 58,3 & 3,0 & 1,5 \\
\hline 5.1 Recomendación & & 91,7 & 8,3 & 1,0 & ,2 & 8,3 & & & 25 & 66,7 & 3,4 & 1,1 & 8,3 & & & 25 & 66,7 & 3,4 & 1,1 \\
\hline 5.2 Frecuencia de uso & & 83,3 & 16,7 & 1,1 &, 3 & 8,3 & & 16,7 & 8,3 & 66,7 & 3,2 & 1,2 & 8,3 & & 16,7 & 8,3 & 66,7 & 3,2 & 1,2 \\
\hline 5.3 Valor económico & & 100 & & 1 & 0 & 8,3 & 16,7 & 8,3 & 8,3 & 58,3 & 2,9 & 1,5 & 8,3 & 16,7 & 8,3 & 8,3 & 58,3 & 2,9 & 1,5 \\
\hline 5.4 Valoración global & & 100 & & 1 & 0 & 8,3 & & 8,3 & & 83,3 & 3,5 & 1,2 & 8,3 & & 8,3 & & 83,3 & 3,5 & 1,2 \\
\hline
\end{tabular}

'Dk/D.' 'Yes' and 'No' expresed in \%frecuency. Items written in original language 
Table 3 Results of the clarity criteria by section (panel of experts)

\begin{tabular}{|c|c|c|c|c|c|}
\hline & \multicolumn{3}{|c|}{$\%$ frequency } & \multirow[t]{2}{*}{$\mathbf{M}$} & \multirow[t]{2}{*}{ SD } \\
\hline & $\mathrm{Dk} / \mathrm{Da}$ & Yes & No & & \\
\hline Section 1 & & 75 & 25 & 1,25 & 0,45 \\
\hline Section 2 & & 66,7 & 33,3 & 1,33 & 0,49 \\
\hline Section 3 & & 83,3 & 16,17 & 1,16 & 0,38 \\
\hline Section 4 & 8,3 & 75 & 16,7 & 1,08 & 0,51 \\
\hline Section 5 & & 91,7 & 8,3 & 1,08 & 0,28 \\
\hline
\end{tabular}

\subsubsection{Second Round}

The results of the second and final round of assessment allowed us to ascertain the experts' degree of satisfaction with the modifications made to the EMAAT for ASD. Figure 3 shows the degree of satisfaction was high in all sections, with the majority of the ratings between 3 and 4 . Section 1 was rated the highest, and section 3 the lowest. The experts' observations clarify this result, as there is a lack of agreement and consensus among professionals on the definition of the autism spectrum, a direct consequence of its heterogeneous nature.

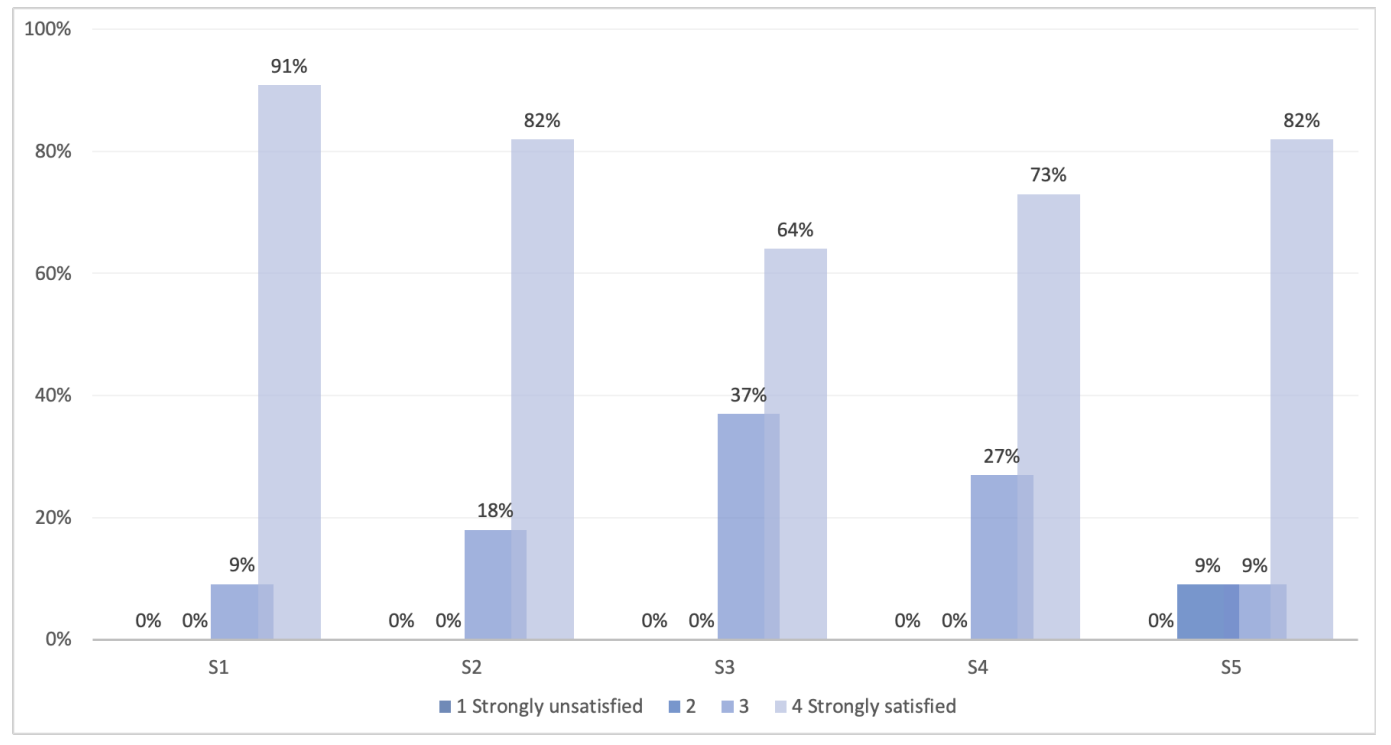

Figure 3 Degree of satisfaction by section in the revised version of the tool.

Below we provide a rough outline the most recent modifications that were made, resulting in a new, refined and improved version of the EMAAT for ASD (prototype 2):

- Slight modifications of some items.

- Modification of the structure, transposing the order of sections 2 and 3 and creating a new section containing descriptive information about the evaluator (section 0 ). 
- Assignment of numerical scores to sections 2 (3 from now on), 4 and 5 to calculate the final score. The remainder of the sections were considered descriptive and classificatory, but not scorable.

\subsection{Pilot Test}

The first round of the principal component analysis (PCA) obtained a Kaiser-Meyer-Olkin (KMO) sampling adequacy of .69 and the result of the Bartlett test of sphericity was significant $(\chi 2(89)=233,81, \mathrm{P}<.001)$. The correlations were greater than .30 and the commonalities were greater than .45 for all items. The three theoretical factors corresponding to sections 3, 4 and 5 of the EMAAT for ASD explained $73 \%$ of the variance. However, five items were discarded ("Evaluación", "Evidencias científicas", "Expresión y comunicación", "Valor económico" and "Puntuación global"), as they received a score of less than .40 in at least one of their factors. The next PCA was conducted using only the two factors that were confirmed by the scree plot (Figure 4). In this last round, the Kaiser-Meyer-Olkin sampling adequacy measure was better, at 0.87 , and the result of the Bartlett test of sphericity was also significant $(\chi 2(43)=113.67 ; \mathrm{p}<.001)$. All the correlations were greater than .30 and the commonalities were .50 . The last 12 items were studied by means of a varimax rotation (as the factors are correlated). The load of every item on its corresponding factor is presented in Table 4.

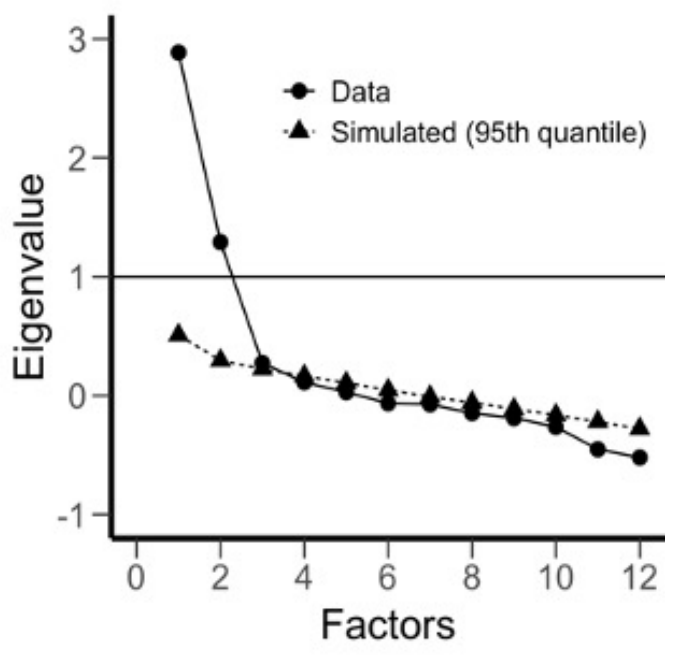

Figure 4 Scree plot

After the factorial study, Cronbach's Alpha values were calculated for the instrument total and for the two final factors: $\alpha($ total $)=0.780 \alpha(\mathrm{f} 1)=0.804 \alpha(\mathrm{f} 2)=0.726$. These values are $>0.7$ and therefore indicate adequate instrument reliability.

Table 5 shows the results of the assessment of criteria validity with Spearman's correlation coefficients between expert scores (in-service teachers) and non-expert scores (trainee teachers). The significant correlations confirm the validity of the instrument in this aspect. 
Table 4 Rotated components matrix

\begin{tabular}{lccc} 
& Factor 1 & Factor 2 & Uniqueness \\
\hline Objetivos de aprendizaje &. & 0.591 & 0.650 \\
Adecuación de los contenidos &. & 0.706 & 0.502 \\
Percepción & 0.420 &. & 0.732 \\
Lenguaje & 0.502 &. & 0.642 \\
Comprensión & 0.620 &. & 0.597 \\
Interacción y navegación & 0.592 &. & 0.634 \\
Funciones ejecutivas & 0.553 &. & 0.671 \\
Interés & 0.649 &. & 0.573 \\
Esfuerzo y persistencia & 0.728 &. & 0.471 \\
Autorregulación & 0.524 & 0.498 & 0.718 \\
Recomendación &. & 0.682 & 0.742 \\
Intención de uso &. & & 0.533 \\
\hline
\end{tabular}

Note. Varimax rotation was applied to correlated factors. Items written in original language

\begin{tabular}{lcccl}
\hline \multicolumn{1}{l}{ Table 5 Spearman correlation } & & & \\
App & $\begin{array}{c}\text { N1-Expertr } \\
\text { (p valor) }\end{array}$ & $\begin{array}{c}\text { N2-Expertr } \\
\text { (p valor) }\end{array}$ & $\begin{array}{r}\text { N3-Expertr } \\
(\mathbf{p} \text { valor })\end{array}$ & $\begin{array}{l}\text { Average } \\
\mathbf{r}(\mathbf{p} \text { valor })\end{array}$ \\
\hline EmoPLAY & $0,502(<0.05)$ & $0,439(=0.06)$ & $0,464(<0.05)$ & 0,468 \\
AutisMIND & $0,531(<0.05)$ & $0,615(<0.01)$ & $0,465(<0.05)$ & 0,537 \\
Joc de Lectura & $0,984(<0.001)$ & $0,756(=0.06)$ & $0,723(<0.05)$ & 0,821 \\
\hline
\end{tabular}

Lastly, with regard to the usability of the tool, Figure 4 shows the average values obtained for the 10 items that make up the SUS:

Item 1: I think that I would like to use this tool frequently.

- Item 2: I found the system to be simple.

- Item 3: I thought the tool was easy to use.

- Item 4: I think I could use this tool without the support of a technical person.

- Item 5: I found the various functions in this tool were well integrated.

- Item 6: I thought there was too much inconsistency in this tool.

- Item 7: I would imagine that most people would learn to use this tool very quickly.

- Item 8: I found the tool very intuitive.

- Item 9: I felt very confident using the tool.

- Item 10: I could use the tool without having to learn anything new.

\subsection{EMAAT for ASD (final version, prototype 3)}

Through the Delphi method, the expert panel validated the theoretical design of the EMAAT for ASD. The pilot test and the dimensional study of the scored sections (3, 4 and 5) revealed the existence of only two underlying factors in the questionnaire, a result which led to further modifications of the instrument: 


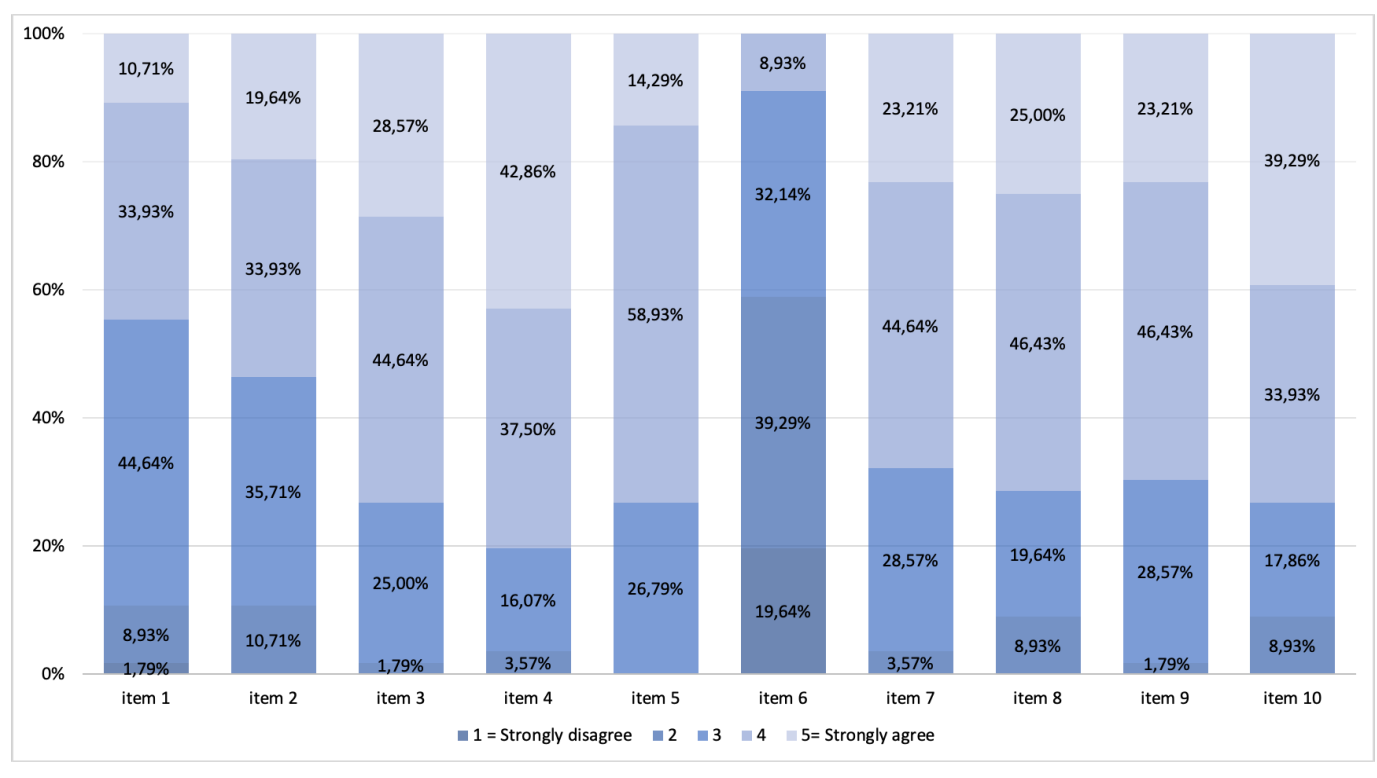

Figure 5 Results of tool usability

- Factor 1 corresponds to section 4, called "características de la aplicación para la inclusión y la accesibilidad educativa", although the "expresión y comunicación" item was discarded.

- Factor 2 corresponds to sections 3 and 5, called "características pedagógicas generales de la aplicación" and "satisfacción profesional". This factor excludes the items "evaluación", "evidencias científicas", "valor económico" and "puntuación global".

The reliability of the instrument is good, indicating that the EMAAT for ASD has sufficient internal consistency with its current items. Meanwhile, the criteria validity indicates that this instrument is valid for the evaluation of apps by both in-service teachers, who are considered expert users, and by less experienced teachers.

The usability results were interpreted based on the definition established by the ISO 9241-11 standard (1998), which describes it as the degree to which a particular individual can utilise a particular product to accomplish certain goals with effectiveness, efficiency, and satisfaction in a certain context. Within this conceptual framework, the teachers' perception of the usability of the EMAAT for ASD was positive, and it can be concluded that this instrument is useful and practical for its intended audience -teachers who make use of apps in educational processes with autistic learners. It is also considered an effective instrument. In other words, it meets its objective: to evaluate the capacity of apps considering the educational needs of autistic people for use in an educational context. Of all the items, the scores for items 4 and 10 concerning the ease of use of the instrument were particularly positive, followed by items 3,5 and 8 . Items 1 and 2 indicate the aspects to be improved in terms of the simplicity of the instrument. They show that the length of the instrument (number of items) is an influential factor in its perceived usability. To all this we should add the dependence of these results on the possibilities and limitations of the technological 
environment used in the digitalisation of the instrument (LimeSurvey).

The purpose of the EMAAT for ASD is to help education professionals identify educational apps that include all the educational-pedagogical and technological characteristics needed to facilitate the learning process of people with autism. To this end, the instrument makes it possible to assess the properties of apps that make them effective, inclusive, and accessible digital educational resources. The questionnaire, available in Spanish and Catalan, consists of 36 items, grouped into six sections (Table 6). Appendix A contains the detailed structure, components and theoretical basis of the EMAAT for ASD. Appendix B is the paper version of the EMAAT for ASD.

At the end of the app evaluation process, the average ratings of the scored items yield:

- A final quantitative score presented on a 5-star scale (common assessment method for this type of software)

- A qualitative score with descriptive feedback for each section.

Lastly, the evaluator has the option of downloading a report containing the results.

\section{DISCUSSION AND CONCLUSIONS}

The EMAAT for ASD is a valid and reliable instrument which has proved useful for evaluating the potential of apps for use in educational contexts with autistic learners. It makes it possible to identify the educational-pedagogical and technological characteristics that such resources must have to facilitate learning among this population. However, the version of the tool presented here should not be understood as the final product, but rather as a product that must undergo further revision.

Future lines of research will focus on the verification of its usefulness and effectiveness, as well as the study of test-retest validity, confirmatory factor analysis and the measure of external validity. In addition, attention will be paid to components (scientific evidence, evaluation) considered important in the selection and evaluation of apps for use in educational processes for people with autism (Armstrong et al., 2012; Fletcher-Watson, 2015), but that have not been included in the factor structure of this instrument or other reference instruments for the evaluation of apps (Stoyanov et al., 2015). Also, in order to enhance the usability of the instrument and facilitate the processing of teacher assessments, another more effective and attractive type of digital platform will be explored, which will act as a benchmark site in the field of apps and educational interventions for people on the autism spectrum.

The primary limitations detected in this study are related to the sample size. A considerable number of experts and teachers participated; however, in relation to the latter group, the number of novice teachers and trainee teachers exceeded that of in-service teachers.

Lastly, we would like to emphasise the importance of initial and ongoing teacher training in ensuring high-quality education for all learners (Fernandez, 2013; Watkins, 2012), always considering and including those with special educational needs, such as people with autism. This issue undeniably requires attention to the implementation of standards such as the 
Table 6 Sections and items of the EMAAT for ASD

\section{Sections/Items}

\begin{tabular}{|c|c|}
\hline \multirow[t]{3}{*}{ Qualifying/Descriptive } & $\begin{array}{l}\text { 0. Datos de carácter personal del evaluado } \\
0.1 \text { Edad } \\
0.2 \text { Género } \\
\text { 0.3 Perfil profesional } \\
\text { 0.4 Experiencia } \\
\text { 0.5 Centro } \\
\text { 0.6 Correo electrónico }\end{array}$ \\
\hline & $\begin{array}{l}\text { 1. Características técnicas y descriptivas de la aplicación } \\
\text { 1.1 Nombre } \\
\text { 1.2 Precio } \\
\text { 1.3 Desarrollador } \\
\text { 1.4 Última versión } \\
\text { 1.5 Sistema operativo } \\
\text { 1.6 Idioma } \\
\text { 1.7 Edad destinatarios } \\
\text { 1.8 Repositorio } \\
\text { 1.9 Tipología } \\
\text { 1.10 Breve descripción }\end{array}$ \\
\hline & $\begin{array}{l}\text { 2. Características pedagógicas de la aplicación con relación al TEA } \\
\text { 2.1 Áreas de afectación } \\
\text { 2.2 Nivel de severidad } \\
\text { 2.3 Funciones cognitivas }\end{array}$ \\
\hline \multirow[t]{3}{*}{ Scoring } & $\begin{array}{l}\text { 3. Características pedagógicas generales de la aplicación } \\
\text { 3.1 Objetivos de aprendizaje } \\
\text { 3.2 Adecuación de los contenidos } \\
\text { 3.3 Evaluación* } \\
\text { 3.4 Evidencias científicas }{ }^{\star}\end{array}$ \\
\hline & $\begin{array}{l}\text { 4. Características de la aplicación para la inclusión y la accesibilidad educativa } \\
\text { 4.1 Percepción } \\
\text { 4.2 Lenguaje } \\
\text { 4.3 Comprensión } \\
\text { 4.4 Interacción y navegación } \\
\text { 4.5 Funciones ejecutivas } \\
\text { 4.6 Interés } \\
\text { 4.7 Esfuerzo y persistencia } \\
\text { 4.8 Autorregulación }\end{array}$ \\
\hline & $\begin{array}{l}\text { 5. Satisfacción profesional } \\
\text { 5.1 Recomendación } \\
\text { 5.2 Intención de uso } \\
5.3 \text { Valor económico* }^{\star} \\
5.4 \text { Puntuación global }^{*} \\
\text { 5.5 Breve valoración }\end{array}$ \\
\hline
\end{tabular}

Note. ${ }^{\star}$ Excluded items for the final score calculation. Items written in original language 
UDL (Capp, 2013; Evmenova, 2018) and the development of TDC (Lázaro-Cantabrana, Usart-Rodríguez, \& Gisbert-Cervera, 2019), which will allow teachers to make the most of the potential of the DT in favour of educational inclusion (UNESCO, 2019).

\section{ACKNOWLEDGEMENTS}

This research was funded with the help of:

Funded by: Secretaría de Universidades de la Generalitat de Catalunya \& European Social Found, Spain

Funder Identifier: http://dx.doi.org/10.13039/501100004895

Award: 2017FI_B 00489

Funded by: Ministry of Science, Innovation and Universities, Spain

Funder Identifier: http://dx.doi.org/10.13039/100014440

Award: RTI2018-096815-B-I00

\section{ADDITIONAL INFORMATION AND DECLARATIONS}

- Data set: Sanromà-Giménez, M., Lázaro Cantabrana, J. L., Usart Rodríguez, M., \& Gisbert-Cervera, M. (2021). Design and Validation of an Assessment Tool for Educational Mobile Applications Used with Autistic Learners [Data set]. Zenodo. https: //zenodo.org/record/4428955

\section{REFERENCES}

Aguilar, M. I. H., \& Villegas, A. A. G. (2016). Análisis comparativo de la Escala de Usabilidad del Sistema (EUS) en dos versiones / Comparative analysis of the System Usability Scale (SUS) in two versions. RECI Revista Iberoamericana de las Ciencias Computacionales e Informática, 5(10), 44-44. https://doi.org/10.23913/reci.v5i10.48

Akker, J. V. D., Gravemeijer, K., Mckenney, S., \& Nieveen, N. (2006). Educational Design Research. Routledge. https://doi.org/10.4324/9780203088364

Allen, M. L., Hartley, C., \& Cain, K. (2016). iPads and the Use of "Apps" by Children with Autism Spectrum Disorder: Do They Promote Learning? Frontiers in Psychology, 7, 1305. https:// doi.org/10.3389/fpsyg.2016.01305

Almenara, J. C., \& Osuna, J. B. (2013). La utilización del juicio de experto para la evaluación de TIC: el Coeficiente de competencia experta. Bordón. Revista de Pedagogía, 65, 25-38. https:// doi.org/10.13042/brp.2013.65202

Álvarez, M. R., \& Fonseca, M. (2016). El método Delphi. REIRE. Revista d'Innovació i Recerca en Educació, 9(2), 87-102. https://doi.org/10.1344/reire2016.9.1916

American Psychiatric Association, APA. (2013). Diagnostic and Statistical Manual of Mental Disorders, Fifth Edition (DSM-5). Retrieved from https://dsm.psychiatryonline.org/doi/book/ 10.1176/appi.books. 9780890425596

Apple. (2020). App Store. Retrieved from https://www.apple.com/es/ios/app-store/

Armstrong, J. E., Bregman, J. D., Farmer, J. E., Huber, D., Kilo, M., Mantovani, J. F., ... Ratcliffe, K. (2012). Autism spectrum disorders: Guide to evidence-based interventions. Consensus 
Publication. Retrieved from https://www.autismeurope.org/wp-content/uploads/2017/08/ interventions.pdf

Autism Association of Western Australia. (2020). Autism Apps.

Autismo España. (2020). Autismo España. Retrieved from http://www.autismo.org.es/

Barthélémy, C., Fuentes, J., Howlin, P., \& Gaag, R. V. D. (2019). Personas con Trastorno del Espectro del Autismo. Identificación, Comprensión, Intervención. Autismo Europa. Retrieved from https://www.autismeurope.org/wp-content/uploads/2019/11/People-with-Autism -Spectrum-Disorder.-Identification-Understanding-Intervention_Spanish-version.pdf

Benito, B. D., \& Salinas, J. M. (2016). La investigación basada en diseño en Tecnología Educativa. RIITE. Revista Interuniversitaria de Investigación en Tecnología Educativa, 0, 44-59. https:// doi.org/10.6018/riite2016/260631

Booth, T., \& Ainscow, M. (2002). Index for Inclusion: developing learning and participation in schools. Centre for Studies on Inclusive Education (CSIE).

Boser, K., Goodwin, M., \& Wayland, S. (2014). Technology tools for students with autism: Innovations that enhance independence and learning. Brookes Publishing.

Brooke, J. (1996). SUS: A “quick and dirty" usability scale. In P. Jordan, B. Thomas, \& B. Weerdmeester (Eds.), Usability evaluation in industry (pp. 189-194). Taylor \& Francis.

Brooke, J. (2013). SUS: A retrospective. Journal of Usability Studies, 8(2), 29-40.

Cabero, J. (2014). Formación del profesorado universitario en TIC. Aplicación del método Delphi para la selección de los contenidos formativos. Educación XX1,17(1), 111-132. https://doi .org/10.5944/educxx1.17.1.10707

Cabielles-Hernández, D., Pérez-Pérez, J. R., Paule-Ruiz, M., \& Fernández-Fernández, S. (2016). Specialized intervention using tablet devices for communication deficits in children with autism spectrum disorders. IEEE Transactions on Learning Technologies, 10(2), 182-193. https://doi.org/10.1109/TLT.2016.2559482

Cantabrana, J. L. L., \& Cervera, M. G. (2015). Elaboració d'una rúbrica per avaluar la competència digital del docent. Universitas Tarraconensis. Revista de Ciències de l'Educació, 1(1), 48-48. https://doi.org/10.17345/ute.2015.1.648

Capp, M. J. (2013). The effectiveness of universal design for learning: a meta-analysis of literature between. International Journal of Inclusive Education, 21(8), 791-807. https://doi.org/10.1080/ 13603116.2017.1325074

CAST. (2018). Universal Design for Learning Guidelines version 2.2 [graphic organizer]. Center for Applied Special Technology. Retrieved from http://udlguidelines.cast.org/binaries/content/ assets/udlguidelines/udlg-v2-2/udlg_graphicorganizer_v2-2_numbers-yes.pdf

Dunn, T. J., Baguley, T., \& Brunsden, V. (2014). From alpha to omega: A practical solution to the pervasive problem of internal consistency estimation. British Journal of Psychology, 105(3), 399-412. https://doi.org/10.1111/bjop.12046

Echeita, G., \& Ainscow, M. (2011). La educación inclusiva como derecho. Marco de referencia y pautas de acción para el desarrollo de una revolución pendiente. Tejuelo: Didáctica de la Lengua y la Literatura. Educación, 12, 26-46.

Escobar-Pérez, J., \& Cuervo-Martínez, A. (2008). Validez de contenido y juicio de expertos: una aproximación a su utilización. Avances en medición, 6(1), 27-36.

European Commission. (2021). HORIZON 2020. En breve. El Programa Marco de Investigación e Innovación de la UE. Oficina de Publicaciones de la Unión Europea. Retrieved from https:// bit.ly/30hRCmb

Evmenova, A. (2018). Preparing teachers to use universal design for learning to support diverse learners. Journal of Online Learning Research, 4(2), 147-171. Retrieved from https://www .learntechlib.org/primary/p/181969/ 
Eynon, R. (2009). Mapping the digital divide in Britain: implications for learning and education. Learning, Media and Technology, 34(4), 277-290. https://doi.org/10.1080/ 17439880903345874

Fernandez, J. (2013). Competencias docentes y educación inclusiva. Revista electrónica de investigación educativa, 15(2), 82-99. Retrieved from http://www.scielo.org.mx/scielo.php

Ferreira-González, I., Urrútia, G., \& Alonso-Coello, P. (2011). Revisiones sistemáticas y metaanálisis: bases conceptuales e interpretación. Revista española de cardiología, 64(8), 688-696. https:// doi.org/10.1016/j.recesp.2011.03.029

Fletcher-Watson, S. (2015). Evidence-based technology design and commercialisation: Recommendations derived from research in education and autism. TechTrends, 59(1), 84-88. https://doi.org/10.1007/s11528-014-0825-7

Fundación Orange \& iAutism. (2014). Apply Autism. Retrieved from http://www.appyautism.com/

Generalitat de Catalunya. (2018). Competència digital docent del professorat de Catalunya. Servei de Comunicació i Publicacions Generalitat de Catalunya. Retrieved from http://ensenyament.gencat.cat/web/.content/home/departament/publicacions/monografies/ competencia-digital-docent/competencia-digital-docent.pdf

Google. (2020). Play Store. Retrieved from https://play.google.com/store/aplicaciones?hl=es

Hitchcock, C., \& Stahl, S. (2003). Assistive Technology, Universal Design, Universal Design for Learning: Improved Learning Opportunities. Journal of Special Education Technology, 18(4), 45-52. https://doi.org/10.1177/016264340301800404

INTF. (2017). Marco Común de Competencia Digital Docente. Retrieved from https://aprende.intef.es/sites/default/files/2018-05/2017_1020_Marco-Com/char"00FAl relaxn-de-Competencia-Digital-Docente.pdf

ISO 9241-11. (1998). Ergonomic requirements for office work with visual display terminals (VDTs) Part 11: Guidance on usability. Retrieved from https://www.iso.org/standard/16883.html

Lancioni, G. E., Sigafoos, J., O'Reilly, M. F., \& Singh, N. N. (2012). Defining Assistive Technology and the Target Populations. In G. E. Lancioni, J. Sigafoos, \& M. F. O’Reilly (Eds.), Assistive technology: Interventions for individuals with severe/profound and multiple disabilities (pp. 17). Springer Science \& Business Media. https://doi.org/10.1007/978-1-4614-4229-5_1

Landis, J. R., \& Koch, G. G. (1977). The Measurement of Observer Agreement for Categorical Data. Biometrics, 33(1), 159-159. https://doi.org/10.2307/2529310

Lázaro, J. L., Estebanell, M., \& Tedesco, J. C. (2015). Inclusión y cohesión social en una sociedad digital. RUSC. Universities and Knowledge Society Journal, 12(2), 44-59. http://doi.org/10 $.7238 /$ rusc.v12i2.2459

Lázaro-Cantabrana, J. L., Usart-Rodríguez, M., \& Gisbert-Cervera, M. (2019). Assessing Teacher Digital Competence: the Construction of an Instrument for Measuring the Knowledge of PreService Teachers. Journal of New Approaches in Educational Research, 8(1), 73-78. https:// doi.org/10.7821/naer.2019.1.370

Lee, J. S., \& Kim, S. W. (2015). Validation of a tool evaluating educational apps for smart education. Journal of Educational Computing Research, 52(3), 435-450. https://doi.org/10.1177/ 0735633115571923

López-Gómez, E. (2018). El método Delphi en la investigación actual en educación: una revisión teórica y metodológica. Educación XX1, 21(1), 17-40. https://doi.org/10.5944/educxx1.20169

Mcquiggan, S., Kosturko, L., Mcquiggan, J., \& Sabourin, J. (2015). Making Accessible Apps: Autism and Visual Impairment. In S. Mcquiggan, L. Kosturko, J. Mcquiggan, \& J. Sabourin (Eds.), A Handbook for Developers, Educators, and Learners (pp. 281-303). Wiley \& SAS Business Series. https://doi.org/10.1002/9781118938942

Mengual-Andrés, S. (2011). La importancia percibida por el profesorado y el alumnado sobre la 
inclusión de la competencia digital en educación Superior: un análisis en Ciencias de la Actividad Física y el Deporte de la Universidad de Alicante (Doctoral dissertation, Universidad de Alicante, Alicante). Retrieved from https://dialnet.unirioja.es/servlet/tesis?codigo=59631

Moher, D., Liberati, A., \& Tetzlaff, J. (2009). Preferred Reporting Items for Systematic Reviews and Meta-Analyses: The PRISMA Statement. Annals of Internal Medicine, 151, 264-269. https:// doi.org/10.7326/0003-4819-151-4-200908180-00135

mSchools. (2020). Toolbox, Aplicaciones educatives validades per docents. Retrieved from http:// toolbox.mobileworldcapital.com/

Navarro, S. B., Zervas, P., Gesa, R. F., \& Sampson, D. G. (2016). Developing teachers' competences for designing inclusive learning experiences. Journal of Educational Technology \& Society, 19(1), 17-27. Retrieved from https://www.jstor.org/stable/jeductechsoci.19.1.17

Ok, M. W., Kim, M. K., Kang, E. Y., \& Bryant, B. R. (2016). How to Find Good Apps: An Evaluation Rubric for Instructional Apps for Teaching Students With Learning Disabilities. Intervention in School and Clinic, 51(4), 244-252. https://doi.org/10.1177/1053451215589179

Osuna, J. B., Gutiérrez-Castillo, J. J., del Carmen Llorente-Cejudo, M., \& Ortiz, R. V. (2019). Difficulties in the Incorporation of Augmented Reality in University Education: Visions from the Experts. Journal of New Approaches in Educational Research, 8(2), 126-126. https://doi.org/ 10.7821/naer.2019.7.409

Papadakis, S., Kalogiannakis, M., \& Zaranis, N. (2017). Designing and creating an educational app rubric for preschool teachers. Education and Information Technologies, 22(6), 3147-3165. https://doi.org/10.1007/s10639-017-9579-0

Petticrew, M., \& Roberts, H. (2006). Systematic reviews in the social sciences: A practical guide. Blackwell Publishing.

Plomp, T., \& Nieveen, N. (2013). Educational Design Research: An Introduction. In T. Plomp \& N. Nieveen (Eds.), Educational Design Research. SLO.

Redecker, C., \& Punie, Y. (2017). European Framework for the Digital Competence of Educators: DigCompEdu. Publications Office of the European Union. http://doi.org/10.2760/159770

Roldán-Álvarez, D., Gomez, J., Márquez-Fernández, A., Martín, E., \& Montoro, G. (2016). Mobile Devices as Assistive Technologies for ASD: Experiences in the Classroom. In M. A. (Ed.), Design, User Experience, and Usability: Novel User Experiences. DUXU 2016. Lecture Notes in Computer Science (Vol. 9747). Springer.

Sabariego, M. (2009). La investigación educativa: génesis, evolución y características. In R. Bisquerra (Ed.), Metodología de la investigación educativa (pp. 51-87). Editorial La Muralla.

Sanromà-Giménez, M., Lázaro-Cantabrana, J. L., \& Gisbert-Cervera, M. (2017). La tecnología móvil. Una herramienta para la mejora de la inclusión digital de las personas con TEA. Psicología, Conocimiento y Sociedad, 7(2), 227-251. http://doi.org/10.26864/pcs.v7.n2.10

Sanromà-Giménez, M., Molero-Aranda, T., Lázaro-Cantabrana, J. L., \& Gisbert-Cervera, M. (2018). Las tecnologías digitales como herramientas de apoyo para la intervención educativa del trastorno del espectro autista: revisión sistemática. In X. Carrera, F. Martínez, J. L. Coiduras, E. Brescó, \& E. Vaquero (Eds.), EDUcación con TECnología: un compromiso social. Aproximaciones desde la investigación y la innovación (pp. 273-281). Edicions de la Universitat de Lleida. https://doi.org/10.6018/riite/2018/327991

Schaaf, D. N. (2018). Assistive Technology Instruction in Teacher Professional Development. Journal of Special Education Technology, 33(3), 171-181. https://doi.org/10.1177/0162643417753561

Seale, J., Garcia-Carrisoza, H., Rix, J., Sheehy, K., \& Hayhoe, S. (2018). A proposal for a unified framework for the design of technologies for people with learning difficulties. Technology and Disability, 30(1-2), 25-40. https://doi.org/10.3233/tad-180193

Selwyn, N. (2004). Reconsidering political and popular understandings of the digital divide. New 
media \& society, 6(3), 341-362. https://doi.org/10.1177/1461444804042519

Stoyanov, S. R., Hides, L., Kavanagh, D. J., Zelenko, O., Tjondronegoro, D., \& Mani, M. (2015). Mobile App Rating Scale: A New Tool for Assessing the Quality of Health Mobile Apps. JMIR mHealth and uHealth, 3(1), e27-e27. https://doi.org/10.2196/mhealth.3422

UNESCO. (1995). Conferencia Mundial sobre Necesidades Educativas Especiales: Acceso y Calidad: Informe final. Retrieved from https://unesdoc.unesco.org/ark:/48223/pf0000110753_spa

UNESCO. (2013). Policy Guidelines for Mobile Learning. UNESCO Biblioteca Digital. Retrieved from https://unesdoc.unesco.org/ark:/48223/pf0000219641

UNESCO. (2016). Educación 2030: Declaración de Incheon y Marco de Acción para la realización del Objetivo de Desarrollo Sostenible 4: Garantizar une aducación inclusiva y equitativa de calidady promover oportunidades de aprendizaje permanente para todos. UNESDOC Biblioteca Digital. Retrieved from https://unesdoc.unesco.org/ark:/48223/pf0000245656_spa

UNESCO. (2019). Marco de competencias de los docentes en materia de TIC. UNESCO Biblioteca Digital. Retrieved from https://unesdoc.unesco.org/ark:/48223/pf0000371024

Vidriales, R., Hernández, C., Plaza, M., Gutiérrez, C., \& Cuesta, J. L. (2017). Informe ejecutivo Calidad de vida y Trastorno del Espectro del Autismo. Retrieved from http://www.autismo.org .es/proyectos/investigacion/calidad-de-vida

W3C. (2015). Cognitive Accessibility User Research. Retrieved from https://www.w3.org/TR/coga -user-research/

W3C. (2018). Web Content Accessibility Guidelines (WCAG) 2.1. Retrieved from https://www.w3 .org/TR/WCAG21/

Watkins, A. (2012). Teacher education for inclusion. Profile of Inclusive Teachers. European Agency for Development in Special Needs Education. Retrieved from https://www.european-agency.org/ resources/publications/teacher-education-inclusion-profile-inclusive-teachers

Weng, P. L. (2015). Developing an app evaluation rubric for practitioners in special education. Journal of Special Education Technology, 30(1), 43-58. https://doi.org/10.1177/ 016264341503000104

Wu, W.-H., Wu, Y.-C. J., Chen, C.-Y., Kao, H.-Y., Lin, C.-H., \& Huang, S.-H. (2012). Review of trends from mobile learning studies: A meta-analysis. Computers \& Education, 59(2), 817827. https://doi.org/10.1016/j.compedu.2012.03.016 